\title{
The Public Power of Judgement: Reasonableness Versus Rationality-Setting the Ball Rolling
}

\author{
Karolina M. Cern ${ }^{1}\left[\right.$ ] José Manuel Aroso Linhares ${ }^{2}[$. \\ Bartosz Wojciechowski ${ }^{3}$ (D)
}

Published online: 8 November 2019

(c) The Author(s) 2019

\begin{abstract}
The chief concern of the paper is to initiate discussion on the difference between the private and public power of judgement. The inspiration comes from Kant and his conception of the power of judgement, customs, morality and provisional law.

Keywords Immanuel Kant $\cdot$ Sittchlichkeit Provisional law $\cdot$ Reasonableness $\cdot$ The public power of judgement
\end{abstract}

\section{The Question of Morality and Customs (Sitten)}

The considerations that follow assume that the fundamental aim of Immanuel Kant's practical philosophy was to lay the critical, architectonic foundations for customs. This is clearly signalled in the title of his first important work in this field: Grundlegung zur Metaphysik der Sitten, which should really be translated as The Groundwork for the Metaphysics of Customs. This foundation, which

Funding The following text was prepared as a part of a research grant financed by National Science Centre (Poland), No. DEC-2015/19/B/HS5/03114 for authors Karolina M. Cern and Bartosz Wojciechowski.

Karolina M. Cern

cern@amu.edu.pl

José Manuel Aroso Linhares

linhares@fd.uc.pt

Bartosz Wojciechowski

bwojciechowski@wpia.uni.lodz.pl

1 Faculty of Philosophy, Adam Mickiewicz University, Szamarzewskiego Street 89C, 60-568 Poznan, Poland

2 Full Professor of Legal Theory and Philosophy of Law (Faculty of Law), University of Coimbra Institute for Legal Research (UCILeR), The University of Coimbra, Coimbra, Portugal

3 Faculty of Law and Administration, University of Lodz, Ul. Kopcinskiego 8/12, 90-232 Lodz, Poland 
critically addresses customs and at the same time consolidates them, is morality, that is, the reasonable moral law. This is because, as John Rawls rightly points out in his Lectures on the History of Moral Philosophy, Kant did not later go on to write (i.e. after Grundlegung) a critique of pure practical reason, but rather, and precisely, a critique of practical reason [16: 147] ${ }^{1}$ —and thus reason related to empirical reason, because it is rooted in sensibility, i.e. in a certain here and now of rational beings; this practical reason can therefore be equated with common sense. Does this mean that Kant simply wants to legitimise common sense- to provide a valid form and the form of validity for it? In a way-yes, precisely! Yet in another way-most certainly not! He sought to set the limits for the legitimate use of common sense (and to legitimize the rational cognition-and the recognition as a norm-of common sense, that is, the aspect of our cognizing and recognizing conducted through our reflection or "discourse", as Kant mentions in his first Critique) thinking most exposed to contingency and transience), which required showing that there is something else at its foundation, due to which in certain situations - of socio-ethical importance, since ethics is crucial for many subjects; not just a single ' $\mathrm{I}$ ' - when common sense operates in in a certain way, it operates legitimately. Quite rightly again, Rawls recommends that many of the issues raised by Kant should be read as constructive engagement with Hume, whom he valued highly [16: 144, 145]. What, then, is crucial for a proper understanding of Kant's practical philosophy?

When subjecting the legitimacy of common sense to critique, Kant did three things at once:

(1) First, he aimed to prove that moral actions can be performed by every ordinary person, and then sought to legitimise such actions. Thus understood, morality is not the domain of elites who could lay claim to the moral authority to rule over ordinary people and direct their conduct. Pauline Kleingeld demonstrates this in her research, arguing that with the passage of time Kant became increasingly "democratic" in his views, in the sense that he came to view every rational being as a citizen of the world, through their being subject to cosmopolitan law, of which we are all co-legislators; however, it has to be stressed that this a process in Kant's development [11]. Furthermore, such cosmopolitanism is only possible in the widest possible social and empirical reality, which is shared with others.

(2) Second, moral actions can be performed by everyone, as users of a specific external-thus empirical-space in which the multi-subject community operates and cooperates. These subjects use the correct, homogeneous apparatus of rational cognition, i.e. common sense. Hence, there are certain social benefits for everyone.

\footnotetext{
1 John Rawls [16: 147]: "Kant says (still in Pref.: II [391]) that he plans to write a critique of pure practical reason; but when this work appears, it is entitled simply Critique of Practical Reason. What happened to the adjective "pure"? (...) Kant's thought is that whereas pure theoretical reason tends to transgress its proper limits, in case of practical reason it is empirical (not pure) practical reason, prompted by our natural inclinations and desires, that tend to transgress its appropriate sphere, especially when the moral law and its basis in our person in not clear to us. Kant insists on the purity of moral law, that is, on the fact that it is an a priori principle that originates in our freedom".
} 
(3) Third, Kant was aware that legitimizing the status quo would be risky, and this was not his philosophical aim. Therefore, he focused on the constructive (positive) limitation of customs by the moral law. As an idea of reason, the moral law is "unrealisable" in the sensual world (although the ideas of reason etc. organise the knowledge of those engaged in empirical reality). The moral law is counterfactual, since it is not subject to any form of sensible realisation, and because the will determined by it produces its own object and this cannot be sensual. Due to this, however, the law can serve as a yardstick for the critical approach, for "testing", and for a non-revolutionary transformation of customs, where relevant. In other words, the extent to which we can say that the laws of ethical life (Sittlichkeit) dogmatically reflect the moral law is the extent to which we are able, after examination, to state that the laws of ethical life are suitable for being considered as components of the laws of nature; the Nature to which we ourselves belong as sensual beings, that is, embedded in time and space. The concept of the laws of nature therefore refers to such "tested" maxims of customs which, in our opinion, we can consider universally valid and binding. In other words, these tested and thus transformed maxims, as morals, constitute a certain ethical life (Sittlichkeit).

It is highly probable that Kant understood that this critical reflection on customs (made through reference to moral law) must be "guaranteed" in the philosophicaltheoretical sense, so that it can be said that everyone should apply the test-or at least nobody can claim that they do not have thus apply it (because, if this were the case, it would legitimize the status quo). In other words, Kant understood the importance of the moral sentiments that the Scottish philosophers wrote about, thereby emancipating ordinary people-in moral terms. However, from Kant's perspective, appealing to sentiments, as the feelings of people in the midst sensate experience, would negate rational and critical reflection on customs (Sitten), which are the sole and immediate product of common sense. This is why Kant devotes so much attention to respect for the law as a sentiment, but also as a feeling resulting from the influence of reason (moral law) on a person embedded in space and time, that is in customs, though a person able to critically reflect on them and reasonably effect their transformation. In other words, the sense of respect is, in our opinion, the equivalent of the sense of justice in the philosophy of the Scottish school of common sense. Kant's notion of respect has a different source than that of the sense of justice, namely reason rather than common sense, and thus Kant calls it respect (for the law). It is to this sense of justice that the great heir to the Scottish Enlightenment, Sir Neil MacCormick - to whom we will return to in the last part of the paper-refers, when he tackles Kant.

This is crucial, because if one does not consider the influence of pure practical reason on empirical reason, one will descend into empiricism [7: 197, 10: 364] and the concepts of good and bad will be drawn from the senses, i.e. from experience, in time and space. As Kant writes:

"Only rationalism of the power of judgement is appropriate for the use of moral concepts, since it takes from sensible nature nothing more than what 
pure reason can also think for itself, that is, conformity with law, and transfers into the supersensible nothing but what can, conversely, be really exhibited by actions in the sensible world in accordance with the formal rule of a law of nature in general" [7: 197]..$^{2}$

According to Kant, the operation of moral law-the power of judgement employing moral concepts in such a way that it tests the maxims created in the sensible world in terms of their compliance with moral law-protects us from falling into a pernicious empiricism.

This means that Kant, who was the first to clearly distinguish between morality and customs, since he aims to critically establish the foundations for customs (Sitten), is also the first to introduce the concept of ethical life (Sittlichkeit). Critically grounded customs - related to the moral law, with which the maxims of ethical life must necessarily be consistent-henceforth does not consist of appeals to certain common rules of action or the straightforward enumeration of virtues (as in antiquity), but is now necessarily comprised of articulations which can be formulated by people here and now, living in and belonging to a certain order of things, being therefore a part of Nature. These articulations are duties imbued with necessity, because they are justified on the basis of the categorical imperative; in other words, they are norms. Therefore, Kant was the first to arrive at the concept of ethical life, since it is he who transforms the concept of Sitten, meaning merely customs, into the concept of ethical life (Sittlichkeit). Ethical life is what is determined by critical reflection from the perspective of the concept of morality. Hence Kant clearly and consistently distinguished ethical life (Sittlichkeit) from morality, a fact which many translations sweep under the carpet, translating both "Sittlichkeit" and "Moralität" with the blanket term "morality". 3

In the light of the above, it can be concluded that Kant's constructivism addresses at least two issues:

(a) the creation of conditions under which the will can be good, i.e. to act justly (cf. Rawls [15]);

\footnotetext{
${ }^{2}$ Changes introduced by us to Mary J. Gregor's translation added in bold. In original [10: 364]: "Dem Gebrauche der moralischen Begriffe ist blos der Rationalism der Urteilskraft angemessen, der von der sinnlichen Natur nicht weiter nimmt, als was auch reine Vernunft für sich denken kann, d. i. die Gesetzmäßigkeit, und in die übersinnliche nichts hineinträgt, als was umgekehrt sich durch Handlungen in der Sinnewelt nach der formalen Regel eines Naturgesetzes überhaupt wirklich darstellen läßt.”.

${ }^{3}$ Latin languages give us however good contrary examples. The consecrated Portuguese and Spanish translations of Sitte are, for instance, respectively costumes and costumbres. (see for example Kant, $A$ metafísica dos costumes, translated by José Lamego, Lisboa: Fundação Calouste Gulbenkian, 2005, and Kant, La metafísica de las costumbres, translated by Adela Cortina Orts and Jesús Marcial Conill Sancho, Madrid: Tecnos, 1989). In the same sense go the French and Italian options, privileging respectively mours and costumi (see for exemple Kant, Métaphysique des mœurs, translation by Alain Renaut, Paris: Flammarion, 1994 and Kant, Immanuel Kant, La metafisica dei costumi, translation by G. Vidari, RomaBari: Laterza, 2016).
} 
(b) the creation of conditions under which we can transform our customs (Sitten) and make some moral progress, i.e. construct ethical life (Sittlichkeit) from reasons formulated on the basis of the categorical imperative.

It has to be borne in mind that for Kant, the notion of Nature refers to what is sensible, and what is sensible is precisely that which is constructed in time and space. After all, Kant conceived of sensibility in non-commonsensical terms: it is through the concept of Anschauungen that sensibility should be understood, that is, through the finite nature of human cognition (Endlichkeit) (through space and time), which Martin Heidegger ingeniously adopted in his philosophy. ${ }^{4}$ And what is found in the sensible realm? People, chairs, houses-of course; but also-political, social and economic institutions. It is to these that Sittlichkeit refers, understood as ethical life. Therefore, Sittlichkeit is the moral law reflected in the sensible world, populated with historical people and their creations-in the here and now; it is presented thusand-not-otherwise in our social, political, etc. life. In other words, Kant provides a conceptual basis for reflecting on authentic life forms and their pluralism, but he did not quite articulate this expressis verbis. In other words, the moral law, which is the idea of reason, is one and only, it is a counterfactual and a yardstick which filters the historical customs which we encounter "here" and "now", so we co-create out ethical lives.

The notion of the laws of nature therefore applies to those rules of customs (Sitten) which have passed through the critical and testing work of the practical power of judgement and are not straightforwardly empirical, so they make up our ethical life (Sittlichkeit).

\section{The Issue of Provisional Law}

Research on the notion of provisional law, which has its origins in Immanuel Kant's philosophy, has been somewhat intensified in recent years, due to the need to develop new tools to for conceptualising a dynamically changing reality - on national, regional (e.g. EU) and global scales. For one group of interpreters, the connotations associated with this concept are negative because, they argue, Kant opposes provisional law to conclusive law (German: peremptorisch): the former only has an uncertain status, since its validity is not absolute. However, in the view of another group of interpreters, the concept of provisional law has entirely different connotations. The latter research approach is represented primarily-but not exclusively-by Tanja Hitzel-Cassagnes and Elisabeth Ellis.

Hitzel-Cassagnes argues that the provisional character of the law in Kant's conception is a key premise for the recognition of "an idea of proceduralisation as a permanent, provisional and reflexive structure of legislation" [4: 151]. According to Hitzel-Cassagnes, this idea should be interpreted together with the assumption that

\footnotetext{
${ }^{4}$ Cf: Martin Heidegger [5, 6]. Naturally, although Kant's reason is unified, its theoretical and practical use (and therefore the issuing of judgments), as well as the criteria for making judgments, are subject to difference. Of course, we are not making the mistake of identifying them here.
} 
(1) "processes of a public use of reason are the ultimate litmus test for formal legislation" [4: 152], as well as with Kant's recognition in the Critique of Pure Reason of the ideas of reason (transcendental) as regulatory ideas, i.e. "unrealisable" ideas, since they lack (always, by definition) material content flowing from experience. Regulatory ideas are employed during argumentation, and it is thanks to argumentation and making public use of reason that progress is possible. In order to be able to achieve this progress (i.e. to 'preserve the idea of progress' [4: 155]), one must assume that the law is, by its very nature, provisional-in other words, that it can be changed, thanks to public discussion and debate. Elisabeth Ellis concurs with this approach, as she also stresses the link between the provisional nature of the law and the idea of progress. What is more, her argument-which emphasises the fact that in the real world we deal solely with provisional law; that is, law which in the near or distant future will be "eligible" for change (in the name of progress) due to the emergence of new or subsequent reasons-leads her to the conclusion that for Kant it is important to practice "pragmatic politics" [2: 9]. This means politics that takes into account the reference of moral principles to the historical-social context, or rather, in the light of the considerations of ethical life and the moral law, it presupposes the reference of the historical-social context to the idea of moral law [2: 3], thanks to which it is possible to formulate certain hypothetical principles and claims. They are hypothetical in the sense that they are formulated in real time by real people-obviously through reference to the normative and counterfactual yardstick of the idea of law-and are revocable in the name of progress, for "impossibility of conclusive legitimacy—of rightness across context of time, place, and policy" [2: 10].

\section{Institutional Constitutionalisation}

The above considerations are intertwined with the concept of institutional constitutionalisation which, in short, means that citizens, co-operating through the exchange and development of public arguments, can

legitimise as well as to de-legitimise and challenge public institutions. Considering the idea of a public use of reason as a procedure of tesing institutional performance with regard to the realization of (the conditions of) freedom advances the claim that the institutional order of a res publica necessarily embodies reflexive and provisional structures. [4: 154]. Cf.: [1]

What Ellis pays particular attention to are "the conditions under which reason-giving practices may be particularly effective" [2: 27]. It is therefore crucial that the reasons developed in public debate can really change-in the name of progressthe institutions that shape our socio-political reality. At the same time, it is no less important to formulate such reasons and claims in order to be able to change reality. In Ellis' view, public institutions are the essence of "Kant's pragmatism", which, in her opinion, results from his adoption of a contractualistic perspective [2: 56ff.]. We 
would like to point out that in the reading of Kant proposed by Ellis, pragmatism entails taking into account the changing socio-political context; thus it is distinct from the "pragmatism" we are familiar with from the philosophy of the twentieth century.

This observation is theoretically pertinent in the context of the ongoing dispute in both the United States and Europe over the proper method of modern legal science: should it be a weighted towards doctrinal reflection or rather in favour of multidisciplinary research, or even interdisciplinary research? ${ }^{5}$ We agree with Rob van Gestel and Hans-Wolfgang Micklitz, who argue that what we are witnessing today, in particular in the area of EU law, is that "an ongoing instrumentalisation of law and legal research decreases the attention for methodology, for theory building" [3: 292]. However, this situation could be remedied by the requisite revitalisation of legaldoctrinal studies, cf. [3:310-312]. Such a response is necessary to secure the weight and authority of the Law, and thus to protect the Law from instrumental use which seeks to implement the particular political or economic goals of the day. However, we also agree with van Gestel and Micklitz that:

"There is no longer one pyramid-like organised legal system in which judges and legal scholars function as 'gatekeepers' who are supposed to guard and maintain the consistency of the system. Instead a plurality of legal systems ('an archipelago instead of an island') has developed in which hierarchy plays a less prominent role than in traditional legal dogmatics." [3: 311-312]

The hierarchy of the legal system no longer plays the prominent role in contemporary legal research that it did at the end of the twentieth century. Furthermore, reflection on the legal system is being redirected towards research on legal institutions and on cooperation within the pluralism of legal institutions, for which multidisciplinary-or even interdisciplinary-research cooperation turns out to be crucial. After all, Neil MacCormick's analyses, presented as early as in Questioning Sovereignty, which focused the rule of recognition and rules of change, have shown that the possibility of changing the law is a key feature of law and the possibility of its development. This possibility hinges on the competencies of public actors, which are key competencies in democratic societies. The public power of judgement is just such a key competency.

\section{The Public Power of Judgement Versus Phronesis as Practical- Prudential Rationality}

In his well-known attempt to reconcile the 'ideology' of the Rule of Law and the commonplace of the 'arguable character of Law', Neil MacCormick reinvents a specific defense of deductivism, concluding not only that justification in Law (even second-order justification) requires universalization (i.e. the presupposition

\footnotetext{
${ }^{5}$ On this issue, see van Gestel and Micklitz [3].
} 
or reconstruction of universal rulings), but also that syllogism provides the rational framework in which "all the other arguments make sense as legal arguments" [13: 42]: this means treating an "apparent antithesis" (between the ideal of legal certainty and the unavoidably contribution of practical-rhetoric reasoning) as a productively "resoluble tension", as well as defending the position that "taking practical reasoning and legal argumentation seriously does not weaken one's respect for the Rule of Law", but rather "enhances it" [13: 254, 280]. The Special Issue which follows endeavours to discuss these conclusions, whilst significantly expanding the scope and possibilities of the corresponding problems. This means confronting (clashing, but also intertwining) two plausible perspectives of jurisdictio, the first one concerned with its potestas (as an autonomous institutionalised public power or as a complex institutional setting), the second one considering the discursive specificity of its judicium (as an autonomous creation and reproduction of communitarian meanings).

(1) The first perspective considers the judiciary and its adjudicative legitimacy under the macroscopic challenges of constitutionalism and the democratic deliberative public sphere, and privileges a self-reflexive post-conventional agenda to examine the public power of judgement as an inseparable activity-the other side of the coin-from the public use of reason. This means exposing a judge's discretion to the discursive criteria imposed by the idea of the public reason, until the point of asking if and to what degree the process of an authentic inclusion of citizens (as authors as well as addressees of law) troubles the 'untouchable' thesis of two separate logics or rationalities (i.e. the scission between processes of law legitimation and processes of law application). This means also exploring new possibilities concerning the institutional accountability of the judiciary.

(2) The second perspective challenges us to explore the rehabilitation of practical philosophy and different contemporary methodological 'translations' or reinventions of Aristotelian phronêsis as plausible expressions of an internal rationalization of legal adjudication (the one whichis seriously taken as an authentic realization of Law). Beyond the well-known alternatives concerning hermeneutic and/ or argumentative possibilities, two other polarized understandings are possible here, one which invokes narrative (and narrative rationality) as the "archetypal legal and rhetoric form" [17: 175], and one which explores the connection judicium/legal system (but also the dialectics problem/system) as the core of legal rationality (considering the constitutive contribution of normative principles and Juristenrecht) [14: 30-34, 76-81, 155-159]. Notwithstanding this diversity (demanding the dominant reinvention of an internal microscopic perspective, even though admitting the significant contributions of external approaches), the issue at stake is not anymore a question of functional or structural doing or social-political legitimation and accountability, it is rather a question of intentionality and sense (involving a specific opportunity of creation and reproduction of aspirations, claims or desiderata, and those ones not only seriously treated as leading warrants, but also as boundaries or limits). 
The productive potential of this distinction becomes very clear when we admit a basic leading question (and this is its crudest formulation): should the democratic legitimation and discursive institutional functioning of jurisdictio limit or overcome (if not reject) the apparently non-deliberative and non-democratic possibilities of practical-prudential rationality (and the specific form of life that those possibilities develop)? In the case of a positive answer, how should the indispensable discursive continuities reflect themselves in the rationality types? In the case of a negative one, is there any plausible intertwining between continuities and discontinuities which should be explored? The simple consideration of these questions (if not a cluster of questions) allows us in fact to propose a thematic development which, notwithstanding the plurality (if not incommensurability) of the congregated conceptions and perspectives, attributes to the fifteen essays collected here the dynamic intelligibility of a quadripartite distribution.

We begin with two steps or lawyers privileging jurisdictio as potestas, the first one devoted to a meta-dogmatic global approach, the second one facing specific institutionalizing issues.

The question which unifies the first step (involving an ensemble of three essays and three exemplarily distinct answers) is certainly the identification of juridically relevant conditions of validity or correctness, and which are explored under the challenge of the binomial law/morality as well as projected in the institutionalization of the Rechtstaat's or Rule of Law's requirements. Whereas the first two essays explore those conditions and/or requirements as more or less explicit components of globally integrated experiences concerning the concept and the nature of Law (and their necessary features or claims), the third one mobilizes them as implicit resources of a more concentrated discussion, concerning the concept of human dignity and the levels of necessity and contingence which its discussion effectively allows. A few words must suffice now to identify those contributions. We begin with José de Sousa e Brito's essay, whose thematic core is certainly the illuminating counterpoint between Kelsen's epistemic normativism and Hart's foundational conventionalism: this counterpoint is not however only an opportunity to rethink the major problems of legal sources and law's identification (as well as the thematic core concerning the unity of the legal system), it is also a precious dialogic (demarcating) resource which—admitting a partial self-suspensive effect (wounding positivistic approaches whenever they are confronted with rule of law requirements) - unveils the reconstitution of a non-positivist recognition thesis; whilst highlighting necessary content-related conditions of validity, as well as acknowledging the limiting role of public reason-if not the reflexive opportunity to treat law reasons as limited ethical reasons (showing source-bound and procedural constraints which do not exist in ethics or practical reasoning in general) - , this one sustains in fact a conceptually necessary experience of Law as a rationally based convention. It is in turn a productive projection of a certain inclusive non-positivism-with its well-known dual-nature thesis (defending the position that Law comprises both a real or factual dimension and an ideal or critical one)—which is at stake in Alexy's essay: whereas the question is now the need to distinguish between the real and the ideal dimensions of constitutional rights-which only the so-called "thesis of adequate moralization" (rejecting the 
effects of overmoralisation and undermoralisation whilst "setting constitutional rights and morality in a correct relation") will be able to pursue-, the reflexive path to be taken involves a clarifying approach of principles theory (with the corresponding weight formula) and Law's claim to correction (seriously taken as a regulative idea), as well as the indispensable reference to the democratic-discursive public sphere and the reconciliation between the real and the ideal which this demands (highlighting balancing as a decisive element not only of Law's statutory and adjudicative practice but also of the "nature" of Law itself). The first step comes to an end with Saulo de Matos's reflection on human dignity: the concentrated discussion of validity claims is now inseparable from the treatment of Law as a "part" of "politics" (if not "political morality"), the development demands however a significant distinction between two possible levels, an abstract universalizing one (claiming an absolute necessary representation of dignity) and a particular, situated and contingent one, associating the content at stake with a way or form of life, when not directly with a particular array of narratives (privileging diverse experiences of disrespect or humiliation); the proposed diagnosis explores the difficulties which trouble the first level, whilst defending an institutional state responsibility, taking into account the social issue of humiliation and the best way to treat it.

The second part preserves the theme of jurisdiction as power (among other state and social powers) - as well as the horizon-context of rule of law claims (and its unavoidable constant recreation) - , the problems at stake correspond now however to the possibilities and limits of institutionalization processes and situations (with arguments explicitly invoking situated backing). Whereas the question posed by Adam Szot has directly to do with the interference of administrative courts (and rulings) with the modelling of the public sphere (not only on micro-management decisions but also on macro policies) — with an answer which acknowledges the factual and normative compatibility of this interference (as an effective, permitted and desirable influence, though not as an indiscriminate one) with the needs and values of Rechtsstaat - , Piotr Juchacz explores the three functions of the deliberative system-epistemic, ethical and democratic-in order to present a model of the good practices of deliberative cooperation in a parliamentary setting, namely, during the work of a Polish Parliamentary Subcommittee.

The third part (integrating the next four essays) introduces the rehabilitation of practical rationality, giving an explicit (smaller or larger) role to the specification of phronêsis and projecting it in the intelligibility of jurisdictio as judgement. The reconstituted "images" are however significantly heterogenous. Three of them attribute the reconstitution stimulus to external points of view (when not explicitly to Law \&... proposals). It is, from the very beginning, the case of Martin Škop, who admits as the leading problem the communication between juridical and non-juridical discourses (and the shaping of Law as a "part of culture") and reconstitutes the plausible connections (also in their legitimizing dimension) from the perspective which only the narrative paradigm allows: this means in fact not only recapturing the specific dimensions which highlight concrete judgements as story-telling processes, but also inscribing the corresponding stories (those which are "communicated in the courtroom", as well as those which sustain interpretive practices and techniques) in 
a significant web of other juridically relevant stories (those which correspond to the legislative prescription, those which accomplish an educational function, and last but not the least, those which assume a meta-narrative legitimizing role, addressed to the "entire legal system or its theoretical description"). It is also the case with Maria Lúcia Oliveira's explicit rethinking of phronêsis as an indispensable step to an effective critical theory of judicial judgment (and an "inclusive practical application of law"): this rethinking involves in fact a chain of relevant assimilations, linking Kant's aesthetic theory and Albena Azmanova's inclusive judicial rhetoric, with the decisive mediation on Hanna Arendt's reconstruction of reflektierende Urteilskraft (and its projection on political judgement, with the corresponding reinvention of deliberative democracy). A parallel concern with an experience of singularity which does not renounce the "hope for universalization" (and the dialectics with sensus communis) inspires Ana Carolina Silvestre's dialogue with the Law \& Emotions movement in general and Terry Maroney's judicial emotion regulation model in particular, being certain that this dialogue is justified not only as an opportunity to recapture Aristotle's concept of phronêsis but also as an attempt to build a bridge leading to Castanheira Neves' jurisprudentialism (and its understanding of the rationale of judicial judgement as a dialectics problem/system). This bridge with jurisprudentialism (and its critical-reflective possibilities) is in fact fully crossed, this time involving however a deliberate internal perspective, in Ana Margarida Gaudêncio's essay: the thematic core is now explicitly the possibility of treating judicial adjudication as judicium and it is the clarifying of the corresponding practical rationality—seriously taken as a subject/subject rationality, involving specific conceptions of the legal controversy's priority and the system's openness (both of them reflected on the experience of normative legal principles)—which justifies a dialogue with formalism and consequentialism, as well as a reconstitution of MacCormick's and Dworkin's arguments.

With this concentration on the methodological level, the path is resolutely open to the fourth and last part, exploring in six different panels the intertwinement between jurisdiction as potestas and jurisdiction as judicium and as such providing different possible answers (or ways of providing answers) to MacCormick leading challenge. Manuel Atienza certainly amplifies this challenge, on one hand as he alludes to the contributions and limits of two different stages of the rehabilitation of argumentative practical rationality (the one which congregates the founding fathers Viehweg, Perelman, Toulmin and Siches, and the one which, with Alexy and MacCormick, develops the so-called standard theory of legal argumentation), on the other hand as he synthesizes the post-positivist legal conception which, combining a reinvention of philosophical pragmatism and (minimal) ethical objectivism with "the idea" of a constitutive dialectics between "an authoritative element and an element of value", allows his own critical argumentative approach towards law. The same different stages are taken into account by J. M. Aroso Linhares, this time specifically in order to question the compatibility between practical reasoning and deductivism, as well as the assimilation of Wróblewski's legacy which, positively answering this question, the standard theory of argumentation exemplarily consecrates: the approach is however an alternative one, on one hand as it refutes this compatibility (and thus discusses Alexy's and Maccormick's approaches), on the other hand as it acknowledges 
the possibilities of Sartor's "doxification of practical reasoning"-all this from the perspective which Castanheira Neves' conception of judicium effectively demands. Dialogue with MacCormick is pursued in Karolina M. Cern's essay, the challenge is however another one, submitting his conception of adjudicative practice (and the correlative claims of normative institutionalization) to the demands of participation which a full experience of democratic polity contemporaneously imposes: this means on one hand acknowledging the way that MacCormick's post-positivism, going beyond the Hartian circle of legal officials, assigns a special role to citizens (as Law's addressees), this means on the other hand, however, highlighting his insufficient treatment of adjudication as public potestas ("the MacCormickian power of judgement is not yet a public power of judgement").

The fourth panel, corresponding to Ivan Padjen's contribution, specifies the tensions at stake in the counterpoint jurisdiction as potestas/jurisdictio as judgment, whilst discussing the way that a renewed search for legal certainty, reacting to the preponderance of judge made law, ignores the demands of systematic interpretation; the proposed solution, involving the determination of an ensemble of plausible criteria, brings together the reinvention of Aristotelian phronêsis and the rethinking of legal system (and juridically relevant re-systematization). In the fifth panel Bartosz Wojciechowski and Marek Zirk-Sadowski return to the institutional situations of administrative courts, developing however a genuinely methodological discussion concerning hard cases, indetermination(s) and judicial discretion, this being concentrated on the "judgment based on rightness or common sense", as well as exemplified though the interpretive practices which the signifier "good faith" (inscribed on a specific tax law EU statutory provision) plausibly allows. Our journey comes to an end with Leszek Leszczyński's exploration of the institutional and methodological relevance of precedential practice in civil law legal orders, less concerned however with the usual discussion of presumptive bindingness (and the more or less heavy burdens of counter-argumentation) than with the specific context of justification which judgements based on judicial rulings effectively demand.

Open Access This article is distributed under the terms of the Creative Commons Attribution 4.0 International License (http://creativecommons.org/licenses/by/4.0/), which permits unrestricted use, distribution, and reproduction in any medium, provided you give appropriate credit to the original author(s) and the source, provide a link to the Creative Commons license, and indicate if changes were made.

\section{References}

1. Cern, Karolina M. 2014. The counterfactual yardstick. Normativity, self-constitutionalisation and the public sphere. Frankfurt am Main: Peter Lang Edition.

2. Ellis, Elisabeth. 2014. Provisional politics. Kantian arguments in policy context. New Haven and London: Yale University Press.

3. Gestel, Rob van, and Hans-Wolfgang Micklitz. 2014. Why methods matter in European legal scholarship. European Law Journal 20 (3): 292-316.

4. Hitzel-Cassagnes, Tanja. 2011. Are we beyond sovereignty? The sovereignty of process and democratic legitimacy of the European Union. In Law and democracy in Neil MacCormick's 
legal and political philosophy, the post-sovereign constellation, vol. 93, ed. José Menéndez and Erik Fossum John., Law and philosophy library Dordrecht: Springer.

5. Heidegger, Martin. 2001. Sein und Zeit. Achtzente Auflage. Max Niemeyer Verlag.

6. Heidegger, Martin. 2010. Kant und das Problem der Metaphysik. Frankfurt am Main: Vittorio Klostermann GmbH.

7. Kant, Immanuel. 2008. Critique of practical reason. Trans. Mary J. Gregor, In Practical philosophy, The Cambridge Edition of the Works of Immanuel Kant. Cambridge: Cambridge University Press, 12th printing, 133-271.

8. Kant, Immanuel. 2008. Groundwork of the metaphysics of morals. Trans. Mary J. Gregor. In Practical philosophy, The Cambridge Edition of the Works of Immanuel Kant, Cambridge: Cambridge University Press, 12th printing, 37-108.

9. Kant, Immanuel. 1995. Grundlegung zur Metaphysik der Sitten. In Werke in sechs Bänden, Band 3. Köln Könemann, 171-269.

10. Kant, Immanuel. 1995. Kritik der praktischen Vernuft. In Werke in sechs Bänden, Band 3. Köln Könemann, 271-483.

11. Kleingeld, Pauline. 2013. Kant and cosmopolitanism. The philosophical ideal of world citizenship. Cambridge: Cambridge University Press.

12. MacCormick, Neil. 2001. Questioning sovereignty. Law, state, and nation in the European Commonwealth. Oxford: Oxford University Press.

13. MacCormick, Neil. 2005. Rhetoric and the rule of law. Oxford: Oxford University Press.

14. Neves, A.Castanheira. 1993. Metodologia jurídica. Problemas fundamentais. Coimbra: Coimbra Editora.

15. Rawls, John. 1999. Kantian constructivism in moral theory. In John Rawls, Collected Papers. ed. Samuel Freeman. Cambridge, Mass., London: Harvard University Press, 303-358.

16. Rawls, John. 2000. Lectures on the history of moral philosophy. ed. Barbara Herman., Cambridge, Mass., and London: Harvard University Press.

17. White, James Boyd. 1985. Heracles' Bow. Essays on the rhetoric and poetics of the law. Madison: The University of Wisconsin Press.

Publisher's Note Springer Nature remains neutral with regard to jurisdictional claims in published maps and institutional affiliations. 